DOI: $10.2478 / \mathrm{MBS} .2014 .024$

Medical and Biological Sciences, 2014, 28/3, 43-50

\author{
ORIGINAL ARTICLE / PRACA ORYGINALNA
}

Przemysław Rybczyński ${ }^{1}$, Joanna Sikora ${ }^{1}$, Beata Augustyńska ${ }^{2}$, Jacek Kubica ${ }^{1}$

\title{
FLUORESCENCE SPECTROSCOPY OF COLLAGEN IN SEVERAL SOLVENTS
}

\section{SPEKTROSKOPIA FLUORESCENCYJNA KOLAGENU W RÓŻNYCH ROZPUSZCZALNIKACH}

\author{
${ }^{1}$ Department of Cardiology and Internal Medicine, Nicolaus Copernicus University, \\ Collegium Medicum in Bydgoszcz, Poland \\ Head: prof. dr hab. n. med. Jacek Kubica \\ ${ }^{2}$ Department of Biochemistry, Nicolaus Copernicus University, Collegium Medicum in Bydgoszcz, Poland \\ Head: dr hab. n. med. Beata Augustyńska
}

S u m m a r y

Introduction. Research was carried out into the influence of microenvironment created by 6 solvents on the spectroscopic characteristics of four types of collagen protein. The solvents were selected on the basis of polarity, $\mathrm{pH}$, the presence of a functional group, as well as their application in fixing biological material for histopathological and spectroscopic examinations. As an amino acid with the highest light-absorbing capacity, tryptophan exhibits the spectral properties of whole protein agglomerates. Protein conformation changes occurring in different environments and changes in functional groups surrounding tryptophan allowed to register protein spectra. The aim of the study was to find out whether changing the collagen microenvironment using six selected solvents allows to differentiate four types of collagen by means of stationary fluorescence spectroscopy.

Material and methods. The research material consisted of four types of human collagen: I, II, III, and IV. The classification of collagen types was based on the spatial arrangement of $\alpha$ chains of each collagen type as adopted by Bornstein and Traub. The emission spectra were recorded with the use of a Hitachi F-7000 spectrofluorimeter and analysed with Origin 8.0 Pro software.

Results. Preliminary tests allowed to determine the most optimal excitation wavelength of polar $(\lambda=270 \mathrm{~nm})$ and non-polar $(\lambda=350 \mathrm{~nm})$ solvents. The observed spectra shapes and maxima at a specific excitation wavelength were characteristic for the corresponding solvent. Differences among the fluorescence spectra of the four types of collagen were not observed.

Conclusions and discussion. Stationary fluorescence spectroscopy does not allow to differentiate four collagen types using the selected solvents.

A major hindrance of this method consists in its high sensitivity to environment changes which may preclude the optimisation of research and in consequence render the approach inferior to techniques using electrophoretic devices, mass spectrometry, or chromatography.

\section{Streszczenie}

W s tę p. Przeprowadzono badania wpływu mikrośrodowiska wybranych sześciu rozpuszczalników na właściwości spektroskopowe czterech typów białka kolagenowego. Rozpuszczalniki zostały wyselekcjonowane na podstawie polarności, $\mathrm{pH}$, obecności grup funkcyjnych, a także wykorzystania ich do utrwalania materiału biologicznego do badań histopatologicznych, jak również badań spektroskopowych. Tryptofan, jako aminokwas o najsilniejszej zdolności absorbowania światła odwzorowuje spektralne właści- wości całych aglomeratów białkowych. Zmiany konformacyjne białka w różnym środowisku oraz zmiany otaczających tryptofan grup funkcyjnych pozwoliły na zare-jestrowanie widm białek. Celem badania było sprawdzenie, czy zmiana mikrośrodowiska kolagenu z wykorzystaniem sześciu wybranych rozpuszczalników pozwoli na różnicowanie czterech typów kolagenu metodą stacjonarnej spektroskopii fluorescencyjnej. 
Materiały i metody. Materiał do badań stanowiły cztery typy kolagenu ludzkiego: I, II, III i IV. Podział typów kolagenu opierał się na przyjętym przez Bordsteina i Trauba ułożeniu przestrzennym łańcuchów $\alpha$ każdego z typów kolagenu. Widma emisji rejestrowane były przy użyciu spektrofluorymetrumetru Hitachi F-7000 i opra-cowane z wykorzystaniem programu Origin 8.0 Pro.

W y n i k i. Badania wstępne pozwoliły na wyznaczenie najbardziej optymalnych długości fali wzbudzenia dla rozpuszczalników polarnych $(\lambda=270 \mathrm{~nm})$ i niepolarnych $(\lambda=350 \mathrm{~nm})$. Obserwowany kształt oraz maksimum widm przy określonej długości fali wzbudzenia był charakterys-

Key words: collagen, fluorescence, spectroscopy Stowa kluczowe: kolagen, fluorescencja, spektroskopia

\section{INTRODUCTION}

Collagen proteins are biopolymers occurring naturally in the human organism and constituting the major building material for most body tissues. Collagen comprises around $25-35 \%$ of total protein mass in the human organism. Its synthesis is regulated by specialised cells called fibroblasts [1]. The cells synthesise collagen proteins in the form of elongated fibrils which constitute a component of tendons, circulatory system vessels, skin, and gastrointestinal and reproductive organs. Collagen is composed of subunits called tropocollagens. A tropocollagen is a molecule which consists of 3 amino acid chains bonding together to form a right-handed helix. A feature characteristic of each polypeptide chain is a tri-amino-acid system with the following configuration: glycine-proline-X or X-glycinehydroxyproline, where $\mathrm{X}$ stands for any amino acid. Glycine constitutes $1 / 3$ of all amino acid residues in a collagen molecule and regulates the stabilisation of fibres by creating hydrogen bonds within the molecule, which in turn leads to the creation of a cross linkage[2]. Despite the fact that the synthesis mechanism for collagen is similar to that of other body proteins, not every stage is common to all polypeptides. Distinct phases, from gene creation to the final product, have been started from transcription and translation of preprocollagen chains, which is the expression of suitable genes, resulting in the creation of polypeptide chains.

The next step of this process is the release of the signal peptide - this stage occurs after protein translocation to the suitable extracellular space. Then begins the posttranslational modifications, which makes collagen different from other proteins hydroxylation of proline and lysine residues. tyczny dla odpowiedniego rozpuszczalnika. Nie zaobserwowano różnic $\mathrm{w}$ widmach fluorescencji pomiędzy czterema typami kolagenu.

Wnioski i dyskusja. Stacjonarna spektroskopia fluorescencyjna nie pozwala na rozróżnienie czterech typów kolagenu $\mathrm{z}$ zastosowaniem wybranych rozpuszczalników. Dużym utrudnieniem $w$ pomiarach fluorescencyjnych stanowi jej wysoka czułość na zmiany środowiska, która niestety może powodować uniemożliwienie optymalizacji badań, dlatego ustępuje miejsca metodom z użyciem aparatury elektroforetycznej, spektrometrii mas lub chromatografii.

Hydroxylation of proline residues is a process, which is characteristic of collagen only and catalysed by prolyl 4-hydroxylase (EC 1.14.11.2) and prolyl 3-hydroxylase (EC 1.14.11.7). The reaction occurs in the presence of vitamin $\mathrm{C}$ (ascorbate) and iron ions in the second oxidation state. Hydroxylation of proline residues is crucial to helix structure formation. Moreover, hydroxylation of lysine residues is a peculiar process to collagen and catalysed by lysyl hydroxylase (EC 1.14.11.4). Hydroxylation of lysyl residues is central to cross-linkage formation and to building carbohydrates into a collagen molecule [3]

Glycosylation is the next important posttranslational modification. It occurs within hydroxyproline and asparagines residues. During glycolisation of hydroxyproline residues, which is also a collagen-specific process, resides on the reaction of attaching a monosaccharide (galactose) or disaccharide (galactosyl-glucose) molecule to selected hydroxylysine residues. The reaction is catalysed by hydroxylysine galactosyltransferase (EC 2.4.1.50) and galactosylhydroxylysine-glucosyltransferase (EC 2.4.1.66). This modification affects the size of protein molecules and additionally lessens their susceptibility to collagenase. The process of glycosylation of asparagine residues occurs exclusively in those protein parts where a superhelical molecule has not formed [4].

Another step is formation of a superhelical structure. It is formation of a disulphide linkage with the involvement of protein disulphide isomerase being a beta-subunit of prolyl 4-hydroxylase, which allows for the creation of a helically wound, three-stranded collagen fibre. Then, conversion of procollagen into collagen (tripocollagen) - enzymatic processing takes 
place whereby propeptides are cleaved (amino-terminal and carboxy-terminal extension).

Finally, formation of a supramolecular structure, corresponding to a given tissue are formed (e.g. fibres of connective tissue), and formation of cross-linkage (the so-called collagen maturation), which is creation of cross-links which allows to acquire resistance to the activity of proteolytic enzymes (proteases). This process results in formation and stabilisation of a correlative spatial structure, which reduces the solubility of collagen in its physiological conditions [5].

The aim of the research was to find out whether changing the collagen microenvironment using six selected solvents allows to differentiate four types of collagen by means of stationary fluorescence spectroscopy.

\section{MATERIAL AND METHODS}

The research material consisted of four types of human collagen. Type I, III, IV were purchased from Sigma-Aldrich, type II was purchased from Merck. The classification of collagen types was based on a division introduced by Bornstein and Traub which concerns the structural build and arrangement of helices comprising a collagen fibre [6]. The most common approach to describing types of collagen uses Roman letters for labelling collagen types and Arabic numerals for labelling alpha chains constituting a molecule. Table I presents collagen types along with the arrangement of molecules complementing a collagen fibre complex and the location of genes coding a given protein into a genome [7,8,9].

Table I. Types of collagen, macromolecule structure and location in the genome [6]

Tabela I. Typy kolagen, skład makroczasteczki oraz lokalizacja w genomie [6]

\begin{tabular}{|l|l|l|}
\hline $\begin{array}{c}\text { Type of collagen } \\
\text { protein/ Typ } \\
\text { kolagenu }\end{array}$ & $\begin{array}{c}\text { Arrangement of } \alpha \\
\text { chains/ Ulożenie } \\
\text { lańcuchów } \boldsymbol{\alpha}\end{array}$ & $\begin{array}{l}\text { Location in the } \\
\text { genome/ Lokalizacja } \\
\text { w genomie }\end{array}$ \\
\hline I & {$\left[\alpha_{1}(\mathrm{I})\right]_{2} \alpha_{2}(\mathrm{I}),\left[\alpha_{1}(\mathrm{I})\right]_{3}$} & $\begin{array}{l}\text { COL1A1(17q21.33), } \\
\text { COL1A2(7q21.3) }\end{array}$ \\
\hline II & {$\left[\alpha_{1}(\mathrm{II})\right]_{3}$} & $\begin{array}{l}\text { COL2A1(12q12- } \\
\text { q13.2) }\end{array}$ \\
\hline III & {$\left[\alpha_{1}(\mathrm{III})\right]_{3}$} & COL3A1(2q32.2) \\
\hline IV & $\begin{array}{l}{\left[\alpha_{1}(\mathrm{IV})\right]_{2} \alpha_{2}(\mathrm{IV})} \\
\alpha_{3}(\mathrm{IV}) \alpha_{4}(\mathrm{IV}) \alpha_{5}(\mathrm{IV}) \\
{\left[\alpha_{5}(\mathrm{IV})\right]_{2} \alpha_{6}(\mathrm{IV})}\end{array}$ & $\begin{array}{l}\text { COL4A1(13q34), } \\
\text { COL4A2(13q34) } \\
\text { COL4A3(2q36-q37), } \\
\text { COL4A4(2q35-q37) } \\
\text { COL4A5, } \\
\text { COL4A6(Xq22) }\end{array}$ \\
\hline & &
\end{tabular}

Collagens of each type were placed in a number of solvents differing in terms of polarity, $\mathrm{pH}$, type of chemical individuum, volatility, hydrophobicity and hydrophilicity. The following solvents were used: acetone, ethyl alcohol, chloroform, xylene, normal saline, distilled water, toluene and acetic acid. The selection of solvents was based on their common usage in the context of histopathological analysis and fixing tissues used in tests. Dyeing histopathology specimens involves the use of solutions for dehydrating and rehydrating tissues in the process of dyeing. A portion of tissues used for autofluorescence measurement is placed directly in a normal saline solution.

Collagens of each type were placed in the abovementioned solutions and subjected to incubation for 24 hours at the temperature of $4^{\circ} \mathrm{C}$. After incubation, the collagen solution was placed in a quartz cuvette and analysed by means of stationary fluorescence using a Hitachi F-7000 spectrofluorimeter. Fluorophores were excited with light of the following wavelengths: 230, 250, 255, 270, 290, 310, 330, 350, 360, 370, 390, $410 \mathrm{~nm}$. The emission spectra were recorded in the range of 200 $600 \mathrm{~nm}$. Reproducibility of measurements was achieved through the use of a quartz cuvette stand and the fixed illumination area of 5x10 mm.

After a preliminary analysis, optimal excitation wavelengths were determined for the purposes of the study. The wavelength was $270 \mathrm{~nm}$ for collagen solutions prepared in normal saline, distilled water, toluene, acetic acid and ethyl alcohol, and $350 \mathrm{~nm}$ for acetone, chloroform and xylene.

The obtained results were analysed with Origin 8.0 Pro software. The results were normalised enabling the elimination of differences ensuing from the concentration of the prepared solutions. Collagen concentration cannot be established because a given collagen type can exhibit varying solubility for each solvent, which in turn precludes determining the molar concentration of the collagen solution.

\section{RESULTS}

The stationary fluorescence measurement covered a total of 32 collagen protein solutions of four types of collagen dissolved in selected solvents. The observed spectra shapes and maxima at a specific excitation wavelength were characteristic for the corresponding solvent. Microenvironment, varying dependent on the solvent used, causes modifications in protein structure 
and fluorophore arrangement, resulting in a change in the optical properties of the prepared solvent.

Microenvironment created by a given solvent induces a change in the spectroscopic properties of collagen fibres. The maximum spectrum for organic solvents was observed at the excitation wavelength of $350 \mathrm{~nm}$, whereas in case of the remaining solvents the wavelength was $270 \mathrm{~nm}$. Figures 1-3 present the spectra of four types of collagen dissolved in three organic solvents: acetone, chloroform and xylene. Figures 4-8 present the spectra of collagen fibre solutions for ethyl alcohol, toluene, acetic acid, distilled water and normal saline.

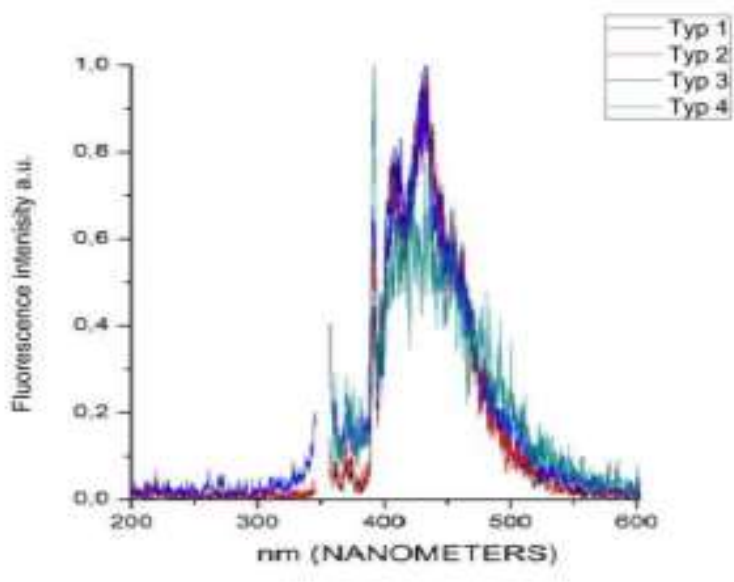

Fig. 1. Spectra of four types of collagen dissolved in acetone; typ 1,2,3,4-numbers of collagen type

Rys. 1. Widma roztworów czterech typów kolagenu rozpuszczone $w$ acetonie; typ 1, 2, 3, 4 -numery typów kolagenu

Figure 1 shows spectra of the examined collagen types dissolved in anhydrous acetone. Spectrum maxima shapes are the same for each of the analysed protein, where the spectrum maximum occurs at the wavelength of $450 \mathrm{~nm}$. Considerable disruptions of the fluorescence signal are observed with regard to this solvent.

Figure 2 presents collagen spectra in chloroform observed at the excitation wavelength of $350 \mathrm{~nm}$. In these conditions, collagen fibres are characterized by two maxima of fluorescence emission - at the wavelength of $420 \mathrm{~nm}$ and $450 \mathrm{~nm}$. No disruptions of the fluorescence signal are observed for this solvent.

Figure 3 shows spectra of the solutions of four collagen types in xylene at the excitation wavelength of $350 \mathrm{~nm}$. Similarly to the case of chloroform, collagens exhibit two maxima of fluorescence, at 420 $\mathrm{nm}$ and $450 \mathrm{~nm}$. No disruptions of the fluorescence signal are observed for this solvent.

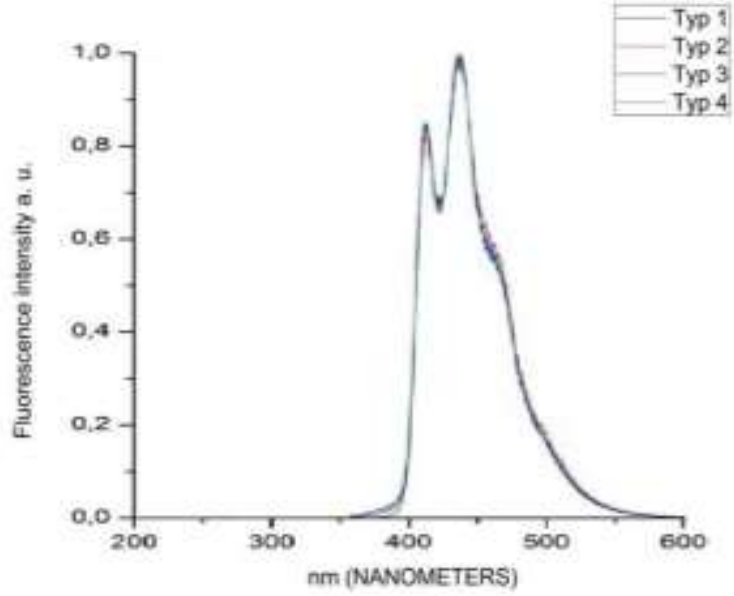

Fig. 2. Spectra of four types of collagen dissolved in chloroform; typ 1, 2, 3, 4-numbers of collagen type

Rys. 2. Widma roztworów czterech typów kolagenu rozpuszczone $w$ chloroformie; typ 1, 2, 3, 4 numery typów kolagenu

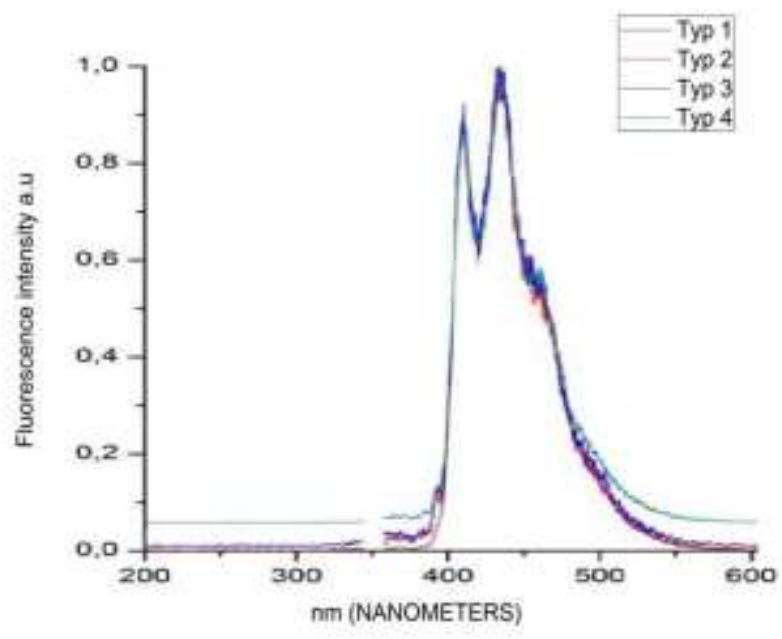

Fig. 3. Spectra of four types of collagen dissolved in xylene; typ 1,2, 3, 4-numbers of collagen type

Rys. 3. Widma roztworów czterech typów kolagenu rozpuszczone w ksylenie; typ 1, 2, 3, 4-numery typów kolagenu

Figure 4 presents spectra of collagens dissolved in anhydrous ethyl alcohol. Upon the use of this solvent, collagens are characterized by two fluorescence emission maxima, at the wavelength of $300 \mathrm{~nm}$ and $580 \mathrm{~nm}$.

Figure 5 presents spectra of collagens dissolved in a solution whose milieu most closely resembles natural/physiological conditions. Natural saline ensures the sustention of chemical potential for every chemical individuum capable of permeating cell membranes. For this solvent, collagen exhibits one sharp fluorescence maximum at the wavelength of $350 \mathrm{~nm}$. 


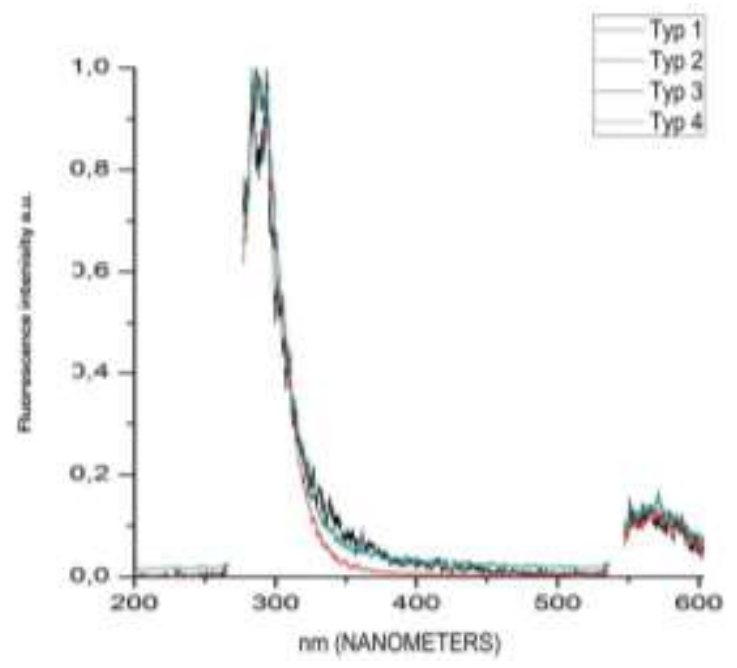

Fig. 4. Spectra of four types of collagen dissolved in ethanol; typ 1,2, 3,4-numbers of collagen type

Rys. 4. Widma roztworów czterech typów kolagenu rozpuszczone w alkoholu etylowym; typ 1, 2, 3, 4 - numery typów kolagenu

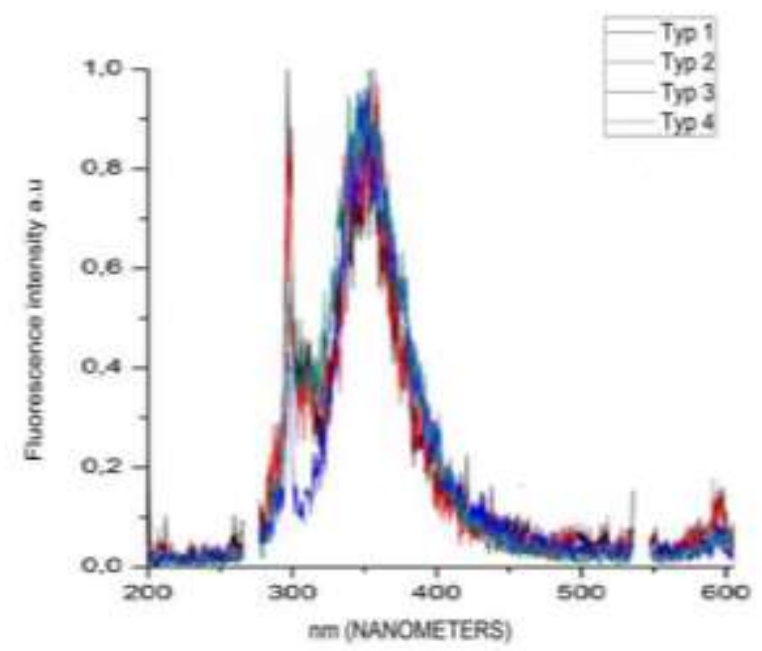

Fig. 5. Spectra of four types of collagen dissolved in saline; typ 1, 2, 3, 4-numbers of collagen type

Rys. 5. Widma roztworów czterech typów kolagenu rozpuszczone w soli fizjologicznej; typ 1, 2, 3, 4numery typów kolagenu

Figure 6 shows spectra of collagens dissolved in distilled water. This solvent does not exhibit chemical potential as it lacks substances which could permeate cell membranes. There is one clear fluorescence maximum at the wavelength of $400 \mathrm{~nm}$. Considerable disruptions of the fluorescence signal are observed with regard to this solvent.

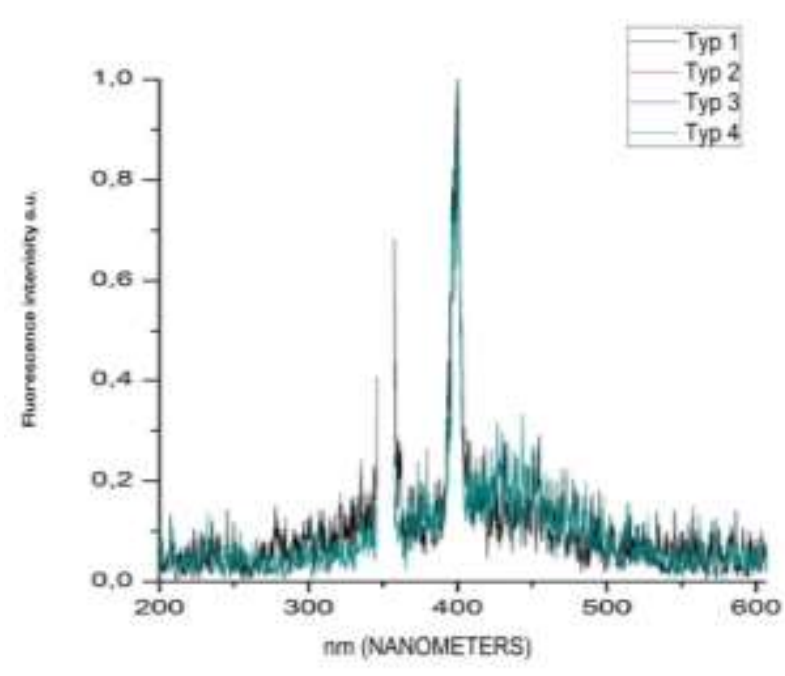

Fig. 6. Spectra of four types of collagen dissolved in distilled water; typ 1, 2, 3, 4-numbers of collagen type

Rys. 6. Widma roztworów czterech typów kolagenu rozpuszczone $w$ wodzie destylowanej; typ 1, 2, 3, 4 - numery typów kolagenu

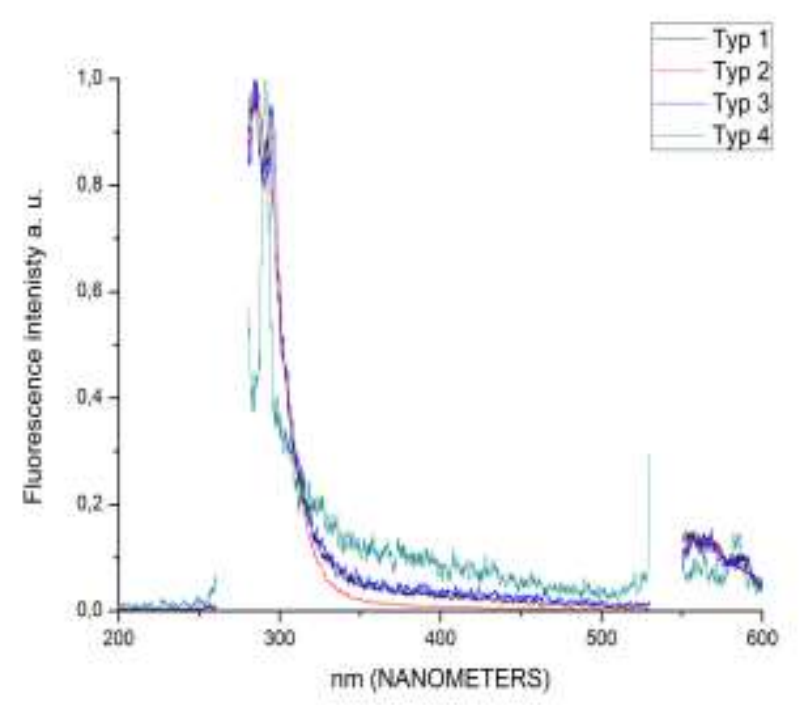

Fig. 7. Spectra of four types of collagen dissolved in acetic acid; typ 1, 2, 3, 4-numbers of collagen type

Rys. 7. Widma roztworów czterech typów kolagenu rozpuszczone w kwasie octowym; typ 1, 2, 3, 4numery typów kolagenu

Figure 7 shows spectra of collagens dissolved in acetic acid. There is one clear fluorescence maximum at the wavelength of $300 \mathrm{~nm}$. Acetic acid is the most optimal solvent for the collagen protein.

Figure 8 shows spectra of collagens dissolved in toluene. There is one clear fluorescence maximum at the wavelength of $320 \mathrm{~nm}$. Toluene is organic solvent however optimal spectra observed at an excitation wavelength $270 \mathrm{~nm}$. 


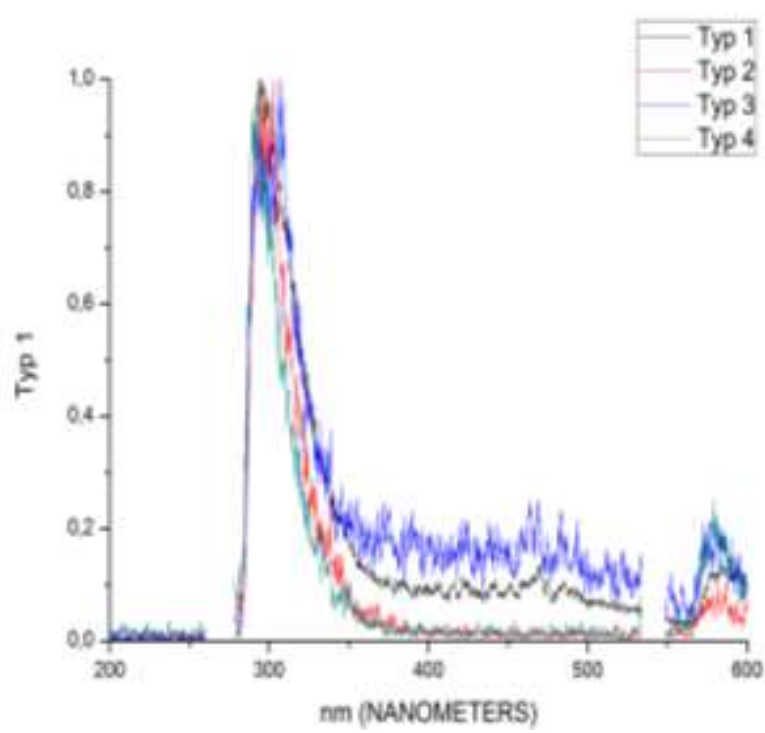

Fig. 8. Spectra of four types of collagen dissolved in toluene; typ 1,2, 3,4-numbers of collagen type

Rys. 8. Widma roztworów czterech typów kolagenu rozpuszczone $w$ chloroformie; typ 1, 2, 3, 4 numery typów kolagenu

\section{DISCUSSION}

Collagen fluorescence depends on the presence of an aromatic amino acid - tryptophan, which is a component of most proteins in the body. Fluorescence of tryptophan rests largely on the environment in which it finds itself, including its polarity and the presence of other molecules which are capable of enhancing or suppressing tryptophan fluorescence [10]. Changes in the emission spectra of tryptophan often occur in answer to subunit association, conformational transitions, substrate binding and denaturation. [11] This is why it is crucial to make attempts at studying collagen fluorescence in other solvents.

It is probable that not only collagen which is purified and prepared for commercial purposes but also that which is isolated from the organism (human/laboratory animals) and acquired from various tissues - connective, osseous or cartilaginous - will demonstrate the same optical characterisation obtained by means of stationary fluorescence spectroscopy.

A significant hindrance in fluorescence measurement consists in its high sensitivity to environment changes which may preclude the optimisation of research and in consequence render the approach inferior to methods using electrophoretic devices, mass spectroscopy, or chromatography. Collagen is most commonly identified with immunohistochemical methods and approaches based on the Western Blot technique; however, it is difficult to prepare antibodies for use in those tests, especially that the affinity of antibodies to collagen might be decreased if the collagen conformation is subject to change. Studied showed that fluorescently labelled collagen mimetic peptides can be used for direct detection of collagenous proteins, which are rich in hydroxyproline by combination of SDS-PAGE and immunohistostaining [12].

The structure of collagen is multifaceted and complex. Its helical symmetry and its persistence within the triple helix is still not fully explained. The interconnection between helical structure in the context of the molecular packing arrangement defines, which parts of the amino acid sequence of the collagen fibril are buried or attainable to the extracellular matrix or the cell[13]. The spectroscopic analysis is very sensitive to any changes associated with the structure of proteins, especially to changes within the protein itself, however, between the protein molecules. Because of the complex nature of the fluorescence phenomenon, all kind of changes concerning the autofluorescent properties of proteins may affect the fluorescence.

Another spectroscopy technique, based on measurements of the coherence of a radiative source, Fourier Transform Infrated Imaging (FT-IR) have been applied to the analyses of tissues, especially in diseases connective or collagen-based tissues, including osteoporosis, osteogenesis etc. The data presented confirm the utility of infrated imaging for measurements and investigations into the micro and molecular structure of cartilage and bone. [14,15] Results from studied showed that using FT-IR, collagen types I and II can be distinguish from each other. Furthermore, there was confirmed that spectral approach can be used for semi-quantitative assessment of tissues with different collagen types.[16]

Fluorescence resonance energy transfer (FRET) have been used to examine energy transfer between two other aromatic amino acids - tyrosine and phenylalanine - during the aggregation behaviour of native collagen in dilute solution. The results from the two-phase diagrams of the intrinsic fluorescence confirmed the predominance of tyrosine in comparison to phenylalanine as well as identified the existence of collagen aggregates with the formation of hydrophobic microdomains [17].

Another technique, which can be used to analyze the structure of collagen in 3D imaging was Raman 
spectroscopy involving measurement of the inelastic scattering of photons. There was analyzed the amide I band-row using polarized Raman spectroscopy (PRS) to characterize the anisotropy of the reaction particles. The samples received from rat tails were used. The technique is generally based on the analysis of the structure of collagen fibers and their spatial conformation. Special selection of a suitable laser allows to anisotropic imaging of particles of the whole protein[18].

Spectroscopic analysis of collagens in particular range of UV can make destructions of helical chains, which may induce incorrect results unrelated to the physiological degradation of collagen. There are many studies characterizing the collagen oxidative damage as a result of ultraviolet irradiation. There has been proven that UV radiation causes a decrease in bonds stabilizing the collagen fibers. The research confirmed that in order to obtain the most reliable results, the collected tissue should be limited to exposure to UV as well as reduce the size of the irradiated field $[19,20]$.

Studies performed on rats showed that the use of HPLC-MS/MS enables a qualitative and quantitative analysis of several collagen types derived from various tissues (skin, tendons, aorta) [21]. Nonetheless, novel, easier and cheaper methods are being sought, which would allow to differentiate collagen types along with identifying their tissue of origin.

\section{CONCLUSIONS}

The analysis of spectrum graphs for four types of collagen dissolved in six selected solvents reveals no differences in spectral shape for each of the studied collagens. Stationary fluorescence spectroscopy does not allow to differentiate the selected collagen types using as solvents: acetone, ethyl alcohol, chloroform, xylene, natural saline and distilled water. The study proves that there are no differences among the four collagen types even in case of using a solvent which is other than the natural environment of the research material.

\section{ACKNOWLAGEMENTS}

This study was supported by a research grant from the National Science Centre, Poland (grant No. N N402 497240)

\section{REFERENCES}

1. Shoulders M. D., Raines R. T., Collagen structure and stability, Annu Rev Biochem. 2009 ; 78: 929-958

2. Banaś M., Pietrucha K., Typy i struktura biatka kolagenowego, CHEMIA SPOŻYWCZA I BIOTECHNOLOGIA, z. 732009

3. Mieke M.H. van Marion, Matrix metalloproteinases and collagen remodelling, 2006, BMTE 06.55

4. Engel J., Bachinger H.P., Structure, Stability and Folding of the collagen triple helix, Topics in Current Chemistry, Volume 247, Springer (2005), pp 7-33

5. Kucharz E. J., Budowa i metabolizm kolagenu oraz jego udział w chorobach kości, Terapia 1999; R.7 nr 10(81), s. 32-35.

6. Bornstein P., Traub W., The chemistry and biology of collagen, Academic Press, 1979, str. 411-632

7. Brinckmann J., Notbohm H., Müller P.K.. Collagen. Primer in Structure, Processing and Assembly, Springer (2005), s. 1-13, 35-77, 86-110.

8. Rest M., Garrone R., Collagen family of proteins, The FASEB Journal vol. 5 no. 13 2814-2823, 1991

9. Gelse K., Poschl E., Aigner T., Collagens-structure, function and biosynthesis, Advanced Drug Delivery Reviews 55, 2003, 1531-1546

10. Lakowicz J. R., Principles of fluorescence spectroscopy, Springer, 2006, 530-573

11. Lakowicz JR. On spectral relaxation in proteins. Photochem Photobiol, 2000; 72(4): 421-37.

12. Yang Li, Daniel Ho, Huan Meng AT all, Direct detection of collagenous proteins by fluorescently labeled collacen mimetic peptides, Bioconjung Chem, 2013, 249(1): 9-16

13. Orgel J., Persikov A., Antipova O., Variation in the helical structure of native collagen, PLoS ONE, 2014, 9(2): e89519

14. Boskey A., Camacho N.P., FT-IR Imaging of native and tissue-engineered bone and cartilage, Biomaterials, 2007; 28(15): 2465-2478

15. Boskey A, Mendelsohn R. Infrared analysis of bone in health and disease. J Biomed Opt. 2005;10:031102031106

16. Hanifi A., McCarthy H., Roberts S., Pleshko N., Fourier Transform Infrared Imaging and Infrared Fiber Optic Probe Spectroscopy Identify Collagen Type in Connective Tissue, 2013, PLoS ONE 8(5): e64822. doi:10.1371/journal.pone.0064822

17. $\mathrm{Wu} \mathrm{K}$, Liu $\mathrm{W}$, Li G, The aggregation behavior of native collagen in dilute solution studied by intrinsic fluorescence and external pro bing, Spectrochim Acta A Mol Biomol Spectrosc; 102: 186-93

18. Galvis L., Dunlop J. W. C., Duda G., at all, Polarized Raman Anisotropic Response of Collagen in Tendon: Towards 3D Orientation Mapping of Collagen in Tissue, PLoS ONE 8(5): e63518. doi:10.1371/ journal.pone.0063518, 2013

19. Jariashvili1 K., Madhan B., Brodsky B., at all, $U V$ Damage of Collagen: Insights from Model Collagen Peptides, Biopolymers. 2012 March ; 97(3): 189-198. doi:10.1002/bip.21725. 
20. Miles C., Sionkowska A., Hulin S., at all, Identification of an intermedia te state in the helix-coil degradation of collage by ultrafiolet light., J Biol Chem, 2000, 275(42):33014-20

21. Pataridis S., Eckhardt A., Mikulikowa K., at all, Identification of collagen types in tissues using HPLCMS/MS, J. Sep. Sci. 2008, 3483-3488
Address for correspondence:

Department of Cardiology and Internal Medicine Nicolaus Copernicus University Collegium Medicum Skłodowskiej-Curie Street No 9

85-094 Bydgoszcz, Poland

e-mail: kikkardiol@cm.umk.pl

tel: (52) 585-40-23

fax: (52) 585-40-24

Received: 6.06.2014

Accepted for publication: 2.09.2014 